\title{
Hikikomori: a COVID-19-járvány egy lehetséges mentálhigiénés következménye
}

\author{
Herold Márton - Herold Róbert dr. - Csuta Cintia dr. - Tényi Tamás dr. \\ Pécsi Tudományegyetem, Általános Orvostudományi Kar, Pszichiátriai és Pszichoterápiás Klinika, Pécs
}

\begin{abstract}
A COVID-19-járvány kényszerú tartós szociális távolságtartást idézett elő az emberek között, ami az egyéb mentális rendellenességek és mentálhigiénés következmények mellett egy sajátos pszichiátriai jelenségre, a hikikomori állapotra hívja fel a figyelmet. A hikikomori tartós és szélsőséges szociális visszahúzódással járó jelenség, melynek kidolgozott kritériumrendszere egyelőre még nem található meg a mentális rendellenességeket osztályozó diagnosztikus kézikönyvekben. Kialakulásának pontos mechanizmusáról még keveset tudunk, de az állapot megjelenése és az internet térnyerése között egyes szerzők szoros kapcsolatot látnak. Klasszikusan az egyén egy társadalmi szempontból megalázó vagy előnytelenül alakuló helyzet következtében vonul vissza fokozatosan egy önként vállalt izolációba. Bár a külvilág nem teljesen érdektelen számukra, azonban a retraumatizáció elkerülése érdekében leginkább online követik a világ történéseit és tartanak kapcsolatot másokkal. A COVID-19-pandémia - különösen a lezárások következményeként előtérbe kerülő online életvitelhez kötődően - jelentős mértékben hozzájárult az internet térnyeréséhez, miközben a valós társas kapcsolatok kényszerüen beszúkültek. Ez a konstelláció jelentős kockázati tényezőnek tekinthető a hikikomori szempontjából, amely hosszú távon a világjárvány egyik nem várt szövődménye lehet, különösen az adolescens és a fiatal felnőtt korosztályban.

Orv Hetil. 2021; 162(41): 1637-1642.
\end{abstract}

Kulcsszavak: hikikomori, COVID-19, pandémia, mentálhigiéné, pszichopatológia, internetfüggőség

\section{Hikikomori: a possible mental health consequence of the COVID-19 epidemic}

The COVID-19 pandemic forced prolonged social distancing between people. This, among other mental disorders and mental health consequences, highlights a specific psychiatric phenomenon: the hikikomori condition. The hikikomori is a phenomenon of persistent and extreme social withdrawal. The condition's established diagnostic set of criteria is not yet to be found in diagnostic manuals classifying mental disorders. Little is known about the exact mechanism of its development, but some authors see a close link between its emergence and the rise of the internet. Typically, the individual gradually withdraws into a voluntary isolation as a result of a socially humiliating or unfavourable situation. Although the outside world is not completely irrelevant to them, they tend to follow online the events of the world and they also keep in touch with others mostly online in order to avoid retraumatization. The COVID-19 pandemic, particularly in relation to the rise of online lifestyles as a consequence of lockdowns, has contributed significantly to the more and more frequent use of the internet, while real social contact has been inevitably reduced. This constellation can be seen as a major risk factor for hikikomori, which in the long term could be an unanticipated complication of the pandemic, especially in adolescents and young adults.

Keywords: hikikomori, COVID-19, pandemic, mental health, psychopathology, internet addiction

Herold M, Herold R, Csuta C, Tényi T. [Hikikomori: a possible mental health consequence of the COVID-19 epidemic]. Orv Hetil. 2021; 162(41): 1637-1642.

(Beérkezett: 2021. július 22.; elfogadva: 2021. augusztus 15.)

\section{Rövidítések}

COVID-19 = (coronavirus disease 2019) koronavírus-betegség 2019; PCR = (polymerase chain reaction) polimeráz-láncreakció
Cikkünk írásának pillanatában a COVID-19-járvány harmadik hulláma lecsengeni látszik, és bizonytalanul állunk a járvány további alakulásával szemben. Ez idáig világszerte már több mint 191 millió fertőzött esetet re- 
gisztráltak, valamint 4,1 millió ember vesztette életét a vírusmegbetegedés következtében. Jó ideig világméretú lezárások zajlottak, és óriási mértékben szorultak be az emberek otthonuk falai közé, sokan kényszerültek egyik napról a másikra - mint ma már látjuk - hosszú távú szociális izolációba. A pandémiával járó szociális izoláció következményeinek vizsgálatakor jusson eszünkbe a hikikomori jelenség, amelynek pontosan a jelentős mértékú szociális visszahúzódás a legközpontibb jellemzője [1].

\section{Mi az a hikikomori?}

A hikikomori egy transzkulturális pszichiátriai jelenség, mely egyelőre nem szerepel sem a Mentális rendellenességek diagnosztikai és statisztikai kézikönyvében (DSM5 [2]), sem a betegségek nemzetközi osztályozására szolgáló kódrendszerben (BNO-10 [3]), mára azonban világszerte elterjedt, súlyos mentálhigiénés és társadalmi problémákat okozó állapotnak tekinthető.

Bár a hikikomori egyelőre hivatalosan nem önálló kórkép, a diagnosztikus kritériumait kidolgozták, sőt többszörös revízión is átesett. A hikikomori tehát a kóros szociális visszahúzódás vagy társas izoláció egy formája, melynek alapvető jellemzője, hogy az egyén fizikailag elszigetelődik otthonában. A diagnosztizáláshoz a következő kritériumoknak kell teljesülniük [4-6]: 1) jelentős mértékű szociális visszahúzódás az egyén otthonába, 2) a folyamatos szociális elszigetelődés legalább 6 hónapja tart, 3) jelentős funkcióromlással vagy distresszel jár együtt. Akinek a folyamatos szociális visszahúzódása kevesebb mint hat, de legalább három hónapja tart, azt prehikikomoriként kell értékelni. A korábbi felfogáshoz képest a legaktuálisabb definícióban sok specifikus pont (a társas részvételek hiánya, a személyes szociális interakciók hiánya, magányosság érzése és a társuló pszichiátriai állapot) került ki a szükséges kritériumok közül, ezek azonban továbbra is nagyon hasznosak az adott hikikomori állapot jellemzésében, illetve a súlyosság és a megfelelő kezelés megítélésében. Fontos kiemelni, hogy ha valakinek van valamilyen pszichiátriai diagnózisa, a definíció megengedi, hogy komorbid állapotként hikikomorinak diagnosztizáljuk az illetőt.

A hikikomori kifejezés a „hiki”, visszahúzódni és a „komori”, elzárkózni igék összetételéből áll. A szó jelentése nagyjából annyit tesz, hogy „elzárva lenni” vagy „elzárkózásba visszavonulni” [4, 7, 8]. Csak Japánban körülbelül 1,1 millió főre teszik a hikiomori állapotú személyek számát, és egyre több országban és kultúrában vélik mára felfedezni az állapot jelenlétét [5]. Tipikus kezdetét - kultúrától függetlenül - a kései serdülőkorra és korai felnőttkorra teszik; gyakran megszégyenülés vagy valamilyen, szociokulturális szempontból jelentős kudarcélményt követően alakul ki [5]. Ilyen élmény lehet például bukás egy kulcsfontosságú vizsgán vagy egy vágyott állás megszerzésének kudarca. Azzal, hogy a tár- sadalom által kijelölt normatív útvonalról letérnek, gyakorlatilag a retraumatizációt kerülik el $[5,7,8]$.

A súlyos állapotú hikikomoriban szenvedők azok, akik gyakorlatilag képtelenek elhagyni otthonukat, de a hikikomorival élők nagy része időnként elhagyja otthonát, például vásárlás vagy hasonló tevékenységek céljából. Leírják, hogy vannak olyanok például, akik nappal otthonukba húzódnak vissza, és éjjel „lógnak ki” a nyitva lévő üzletekbe vásárolni, amikor kevés ember van a nyilvános helyeken $[4,5]$.

Aszerint is csoportosíthatjuk a hikikomori állapotú személyeket, hogy egyedül vagy családjukkal élnek-e. Az utóbbiak száma jóval nagyobb, az egyedül élők jelentősen kevesebben vannak, és általában jóléti juttatásokból élnek [9]. Az egyedül vagy családban élő típusokon belül további fokozatokat határozhatunk meg az állapot súlyossága szerint [4]. A különböző szinteken más és más terápiás lehetőségekben is kell gondolkodnunk. Az egyedül élők közül a magasabban funkcionáló szinten vannak azok az egyének, akik egyedül élnek, de időről időre direkt interakciókba bonyolódnak a külvilággal, hetente legalább 2-3 alkalommal. Az alacsonyabb, második szinthez tartoznak azok, akik egyedül élnek, és nem igazán lépnek direkt interakcióba a külvilággal, pusztán hetente 1 vagy annál is kevesebb alkalommal.

A családban élő hikikomorik legmagasabban funkcionáló szintjéhez - egyedül élő társaikhoz hasonlóan azok tartoznak, akik néha (heti 2-3 alkalommal) elhagyják otthonukat, és direkt interakcióba lépnek másokkal a külvilágban. Második szintjüket azok képviselik, akik ritkán (heti 1 vagy kevesebb alkalommal) hagyják el otthonukat, és lépnek direkt interakcióba másokkal, emellett azonban időnként direkt kommunikációba lépnek a velük együtt élőkkel. A harmadik, legrosszabbul funkcionáló szintet azok képviselik, akik otthonukon belül is ritkán hagyják el szobájukat (heti 1 vagy kevesebb alkalommal), és kerülik a direkt kapcsolatot a velük együtt élőkkel is [4].

Aszerint is különbséget kell tenni, hogy elsődleges (idiopátiás) hikikomori állapotról van-e szó, vagy valamilyen pszichiátriai kórképhez társuló komorbid állapotról [6]. A társuló kórkép jelentősen befolyásolja, hogy milyen terápiás lehetőségek érhetők el az állapot kezelésére. Ennek szemléletes példája, hogy szkizofréniához is gyakran társul hikikomori állapot [10], amely egészen más kezelést igényel, mint ha nem pszichotikus zavarhoz kapcsolódó hikikomoriról lenne szó. Egy kis elemszámú nemzetközi kutatás [6] azt az eredményt mutatta, hogy a leggyakoribb társuló állapot az elkerülő személyiség zavar. Egyesek egyenesen odáig mentek, hogy az elkerülő személyiség magának a hikikomori állapotnak az alapja $[10,11]$. Mindezeken túl hangulatzavarok (például major depresszió), szorongásos zavarok (például szociális fóbia), kényszerbetegség, evészavarok vagy pervazív fejlődési zavarok is gyakran feltárhatók a hikikomori állapot mellett [12]. 


\section{Hikikomori és az internethasználat}

$\mathrm{Az}$ állapot első leírásai és az internet térnyerése egyaránt az 1990-es évekre tehető, mely koincidencia mellett nem érdemes elmenni. Az internetes társadalom megszületése lehetóvé tette, hogy az embereknek kevesebbet kelljen kimozdulniuk és közvetlenül interakcióba lépniük környezetükkel, hiszen rengeteg dolog, mint például a vásárlás vagy a szórakozás vált elérhetővé az otthon kényelméból. A világháló elterjedése a pozitív hozományai mellett azonban olyan negatív következményekkel is járt, mint a problémás internethasználatnak és az internetes addikciós zavaroknak a megjelenése [13, 14]. Bár kezdetben a hikikomorit kifejezetten japán kulturális jelenségnek kiáltották ki, az elmúlt időben számos más országban fedeztek fel hasonló eseteket, és mára már egyértelmúen globális mentális egészségügyi problémává vált. Kialakulásának oka nem teljesen tisztázott, de egyes szerzőknek erős feltevéseik vannak arra vonatkozóan, hogy az internet elterjedése a jelenség megszületésének egyik legjelentősebb hozzájáruló tényezője volt $[4,15]$.

A hikikomorik központi jellemzője a „szociális halálra” való vágy, miközben a fizikai halált igyekeznek elkerülni. Furuhashi és Bacqué azt írják róluk: „Szeretnék, ha a társadalom elfeledné öket, de ök nem tudják elfelejteni a társadalmat” [7]. Ezzel arra utalnak, hogy bár fizikailag kivonulnak a társadalomból, a világ történéseit követik, és kapcsolatokat tartanak online játékok és közösségi média segítségével. Ha vannak barátaik, akkor túlnyomórészt olyanok, akikkel kizárólag az online térben „találkoznak" [4].

Kérdés, hogy a szociális visszahúzódás ágyaz-e meg az internetfüggőség kialakulásának, vagy az internetfüggőség készteti az egyént szociális visszahúzódásra [15]. Ha az előbbit tekintjük, akkor arra gondolhatunk, hogy a hikikomorival élők legtöbbje azért húzódik vissza, hogy elkerülje a való világ fájdalmas stresszhatásait, mint az iskolai bántalmazást vagy a kudarcokat az iskolában, munkahelyen. A szociális visszahúzódást követő kezdeti időszakban óriási megkönnyebbültséget élhetnek át az ilyen egyének. Amikor azonban hónapok, esetleg évek óta tart a visszavonulás, a magányosság érzése egyre inkább elhatalmasodik rajtuk. Az internet ilyenkor önsegítő eszköz lehet a magányosság érzésének enyhítésében. Ahogyan az interneten megélik a kapcsolódást másokhoz a különböző eszközökön keresztül - olyan tevékenységek közben, mint az online játék -, megfeledkezhetnek magányosságuk érzéseiről. Ez lehet a fó út, amely a hikikomori állapottól az internetfüggőséghez vezet [15].

Ezzel ellenkezőleg pedig az is elképzelhető, hogy az internethasználat vezet a hikikomori állapothoz. Az internet elterjedése elsorvasztott rengeteg lehetőséget a direkt kommunikációra és a társadalomba való kimerészkedésre, ami a modern társadalmakban a hikikomori jellegű állapotok megemelkedéséhez vezetett. Olyan, interneten végezhető tevékenységek váltak mára min- dennapjaink részévé, mint a folyamatos információgyưjtés, az online vásárlás, a videónézés, az internetes játékok és a másokkal való webalapú kommunikáció. Az internet kényelmesen és azonnal juttat minket kielégítő információkhoz, és nagyon gyorsan képes távolról összekapcsolni minket családtagokkal, barátokkal, személyes („faceto-face") interakciók nélkül. Ezek a megoldások a modern embert egyre inkább hajlamossá teszik arra, hogy fizikai izolációba kerüljenek. Néhányan olyannyira az internetes világ függőjévé válnak, hogy nem mozdulnak ki otthonukból, és szociálisan visszahúzódnak [15].

Nagyon valószínú, hogy a hikikomori kialakulásában mindkét mechanizmus relevánsnak tekinthető. A szociális visszahúzódás az internethasználatban találhat bizonyos fokú társas interaktivitást, míg a modern digitális világ megágyazhat a szociális izolációnak.

\section{Pandémia és hikikomori}

A járványügyi lezárások, korlátozások oldódásával merőben más gazdasági és szociális életbe csöppenünk vissza, amely jelentős, mentális egészséggel összefüggő kihívásokat tartogathat [7, 16]. Előzetes kínai adatok [17] alapján például azt jósolják, hogy közel ötszörösére emelkedhetnek a szorongásos és depressziós panaszok a COVID-19-járvány hatására. Ugyanakkor ezek a számítások nélkülözik azokat az illetőket, akik a rendszer számára "láthatatlanok", amely társadalom elötti láthatatlanság a hikikomori állapotú személyek egyik központi vágya [7].

Anekdotikus példák szerint Japánban (és valószínúleg sok helyen máshol is a világban) sokan rettegnek attól, hogy közösségükben kiderül pozitív COVID-19-teszteredményük, ami miatt inkább hezitálnak, hogy készüljön-e egyáltalán PCR-tesztjük [1]. Mindez nagyon hasonlít arra, ahogyan a hikikomori egyének és családjuk kerülik a kapcsolatot a pszichiátriával, nehogy diagnosztizálásra kerüljön bármi feltárható probléma. Japánban és más ázsiai országokban mindez mélyen kulturális beágyazottságú jelenség. Ez a tradicionálisan-kulturálisan beágyazott szégyenérzet, a haji, és a társas kiközösítés, a murabachibu, melyek a korábbi járványok és gazdasági válságok idején is sok embert taszítottak öngyilkosságba [4, 18]. A szerzők az első COVID-19-hez köthető öngyilkossági esetek [19] alapján megerősítettnek látják a jelenséget. Ebből is látszik, hogy a stigmatizáció megelőzése mennyire fontos feladat a járványkezelésben, egyrészt a vírusterjedés megelőzése, másrészt a stigmatizáció következményeinek - depresszió és öngyilkosság elkerülése szempontjából.

A pandémia általánosan - megfertőződéstől függetlenül - komoly stresszt okoz a társadalom tagjainak [20]. Nagyon gyakori a járványhelyzetben az akut stresszreakció jelentkezése, illetve a szorongás, lehangoltság érzése, a kilátástalanság és a reménytelenségérzés. Alvászavarok és suicid gondolatok is gyakran megjelennek a járványidőszakban $[21,22]$. A pandémia megfékezésére szolgá- 
ló korlátozások a társas kapcsolatok beszúküléséhez vezetnek [19]. A pandémiával kapcsolatos vizsgálatok azt mutatják, hogy a járványhelyzet következtében fellépó krónikus pszichológiai distressz, a mentális zavarok és a suicid viselkedés egyre jelentősebb közegészségügyi problémát jelentenek [16]. Ezek a tényezők a hikikomori állapotnak is kellőképpen megágyazhatnak [7]. Rizikótényezők lehetnek a korábban fennálló egyéb mentális betegségek, és különösen veszélyeztetettek azok, akiknek a járvány miatt súlyos mértékben kisiklott az életük [7].

Mindezek mellett azt láthatjuk, hogy a pandémia jelentős mértékben hozzájárult az internet még nagyobb térnyeréséhez. Hétköznapi tapasztalatunk is az lehetett, hogy sokkal nagyobb mértékben támaszkodunk az internet nyújtotta információs és kommunikációs technológiákra. Rengeteg szektort mentett meg az internetes technológia. Lehetővé tette, hogy otthonról dolgozzunk, tanuljunk, és nem utolsósorban a járványhelyzet kezelésében is fontos tényező volt az információ gyors áramlása. Az izolációval járó magány oldásában is sokat segített, hogy távolról is lehetővé vált kapcsolatot tartani családtagokkal, barátokkal az internet nyújtotta lehetőségek révén. Ugyanakkor legalább ilyen mértékben hozott újfajta kockázatokat a pandémia alatti „internetes boom” [23-25]. Egy kínai kutatás [25] a COVID-19-járvány alatt az internetfüggőség előfordulásának és súlyosságának növekedéséról számolt be. A járvány előtti időszakhoz képest jelentősen megnőtt az internettől való függés, az interneten töltött időtartam, valamint többen számoltak be súlyos internetfüggőségről. Aki korábban is súlyos internetfüggőnek számított, az pedig a korábbinál is erősebb függőséget mutatott.

Tekintetbe véve, hogy az internet térnyerése és a hikikomori között szoros kapcsolatot látnak, a pandémia alatti információs és kommunikációs technológiák használatának látványos növekedését nem hagyhatjuk figyelmen kívül mint a hikikomori állapot lehetséges rizikótényezőjét. Mindezek mellett a sokakat érintő kényszerú, hosszú távú - hat hónapnál tovább tartó - szociális izoláció, a társas kapcsolatok beszúküulése és azok a társadalmi-gazdasági változások, amelyek megváltozott életkörülményeket, lehetőségeket, potenciális kudarcokat hoznak magukkal a fiatalabb munkavállalók és a pályakezdők számára, szintén komoly veszélyeztető tényezők a tartós szociális visszahúzódás ezen fajtájára. Mindezeket önmagában is erősíti, hogy jelentős mentálhigiénés következményei, kockázatai vannak az ún. „koronafóbiának" és a vírussal való megfertőződésnek is [16]. Maga a járványhelyzet akut stresszreakciót, létbizonytalanságot, szorongással, lehangoltsággal járó állapotokat okozhat, míg a megfertőződés pszichés következményei között ott vannak a depressziós és szorongásos zavarok, a poszttraumás stressz zavar és az öngyilkossági rizikó. Mindezek szintén súlyos veszélyeztető tényezők a hikikomori állapot kialakulásában.

\section{Terápiás lehetőségek}

Ilyen mértékű és tartós szociális visszahúzódás mellett igencsak nehezen és későn kerülnek a hikikomori állapotban szenvedő egyének bármiféle mentálhigiénés ellátásba. Japánban átlagosan 4,4 évnek kell eltelnie a visszahúzódás kezdetétől, hogy először támogatást kapjanak [4].

Egy útmutató négylépcsős programot javasol. Az első lépés a családi támogatás és a család együttmúködésének megnyerése, hogy egyáltalán meg tudjuk ismerni az illetőt. Ezt követi a hikikomorival élő személy egyéni támogató terápiás kapcsolatba vonása. A harmadik lépcsőfok az átmeneti csoportos szituációk (például csoportterápia) alkalmazását képviseli. Az utolsó, negyedik lépés pedig a társas helyzetekben való részvétel elősegítése és támogatása [4].

Az ellátás megkezdése előtt elengedhetetlen, hogy multidimenzionális módon értékeljük az adott esetet. Fontos figyelembe venni a kezdeti életkort, a kiváltó életeseményeket és az állapot súlyosságát (a visszahúzódás időtartama, a szoba/otthon elhagyásának gyakorisága, a családtagokkal vagy barátokkal való kapcsolat) [4]. Segíti az állapot értékelését a 2-3 perc alatt elkészíthető önkitöltős Hikikomori Kérdőív (HQ-25) [26], amely alapján széles körben és könnyen diagnosztizálhatóvá vált az állapot. Mindezek mellett létfontosságú feltárni a - nagyon gyakran meglévő - komorbid pszichiátriai (esetleg szubklinikai) állapotot is. A személyiség, a kötődési stílus és az internetfüggőség tendenciák értékelése is kifejezetten ajánlott. Komorbid pszichiátriai állapotok esetén az adott kórkép kezelési útmutatója alapján kell végezni a kezelést [4].

A hikikomorival élők nem valószínú, hogy segítséget fognak keresni, így, ha családban élnek, a családi intervenciók döntő fontosságúak. A családtagok sokszor tehetetlenek az állapottal szemben, megeshet, hogy nincsenek ismereteik sem általában a mentális betegségekról, sem a hikikomori állapotról, így akár sok éven keresztül vakok maradhatnak a problémára anélkül, hogy segítséget keresnének. Számos esetben a megbélyegzéstől tart a család, vagy attól félnek, hogy gyermeküket egy életre bezárják valamilyen félelmetes pszichiátriai intézménybe. Néhány hikikomori agresszív viselkedést tanúsít családtagjaival szemben, és a szülők tartanak a megtorlástól, ha szakmai segítségért fordulnak. Ezek miatt nagyon fontos, hogy a közvetlen családtagok oktatva legyenek a mentális betegségek és az adott állapot vonatkozásában, valamint a beavatkozási lehetőségekról [4].

Hasznos lehet - különösképpen a kezdeti időszakban - az is, ha közösségi módszereket alkalmazunk. Orvosok, ápolók, pszichológusok vagy szociális munkások látogatása a hikikomori személyek otthonában sokat segíthet mind a családnak, mind az érintett egyénnek [4].

Egyesek úgy vélik, hogy az állatok (például kutya, macska) vagy Japánban például az állatszerú robotok alkalmazása segíthet abban, hogy a hikikomori személy 
érzelmi kapcsolódást éljen meg valaki felé, így oldani lehet magányosságát, ami az egyik első lépés lehet a szociális interakciók felé. A különböző, kiterjesztett valóságon alapuló applikációk is segíthetnek az egyént rávenni arra, hogy elsődlegesen egy virtuális játékot játszva, de elinduljanak a külvilág felé [4].

A specifikus pszichoterápia is alkalmas kezelési módszer lehet a hikikomori állapotban (Saito 2010). Az egyéni vagy csoportos pszichodinamikus módszerek például hatékonyak az interperszonális nehézségek oldásában. A téma egyik szakértője, Kato [4] Fairbairn elméletére hivatkozik, amely segíthet megérteni a hikikomoriban megmutatkozó izolációt a magány és az egyedüllét dimenziójában [27]. Kato kiemeli, hogy Fairbairn elmélete alapján a visszahúzódásra, elvonulásra való hajlam eredendően hozzátartozik a humán létezéshez. Az internet, a mobiltelefonok és más mobileszközök elterjedésével azonban bárhol legyünk is, mindig kapcsolatban állunk valakivel. Ennek következtében a privát világok hirtelen nyilvános látótérbe kerülnek, ami egy olyan, modern társadalmat hoz létre, ahol szinte lehetetlen „komfortosan egyedül lenni”. Az állandó kapcsolatban levés, a magánélet és a nyilvánosság határainak elmosódása vezethet ahhoz, hogy egyesek a visszavonulás ilyen szélsőséges formáját választják [4]. A hikikomori állapot visszahúzódása talán annak a modern embernek a kétségbeesett cselekedete, aki elvesztette az egészséges elvonuláshoz szükséges teret [28]. Az állapot megértésének kulcsa az lehet, hogy a hikikomoriban szenvedőknél a cél az, hogy vissza tudják szerezni azt a mentális teret, ahol kényelmesen, biztonságosan egyedül tudnak lenni, de nem kell magányossá válni, nem kell megszakítani hús-vér interperszonális kapcsolataikat. Ehhez az élményhez segíthet hozzá például a terápiában a beszélgetésben bekövetkező csendek tolerálásának képessége, amikor sem a kliens, sem a terapeuta nem szólal meg, de ott vannak együtt az adott térben, osztoznak a csenden, és figyelnek egymásra [4]. Amikor két ember együtt, de csendben van, akkor tud megszületni az az „egyedüllétre való képesség”, amelyről Donald Winnicott [29] munkásságában olvashatunk. Az egyedüllét azonban nem azonos a magánnyal, az egyedüllétben is paradox módon valaki valójában jelen van [30]. Ilyen egyedüllét például az is, amikor a kisgyermek egyedül játszik, de a távolban látja, érzékeli édesanyja jelenlétét. Winnicott elméletében az egyedüllétre való képesség a fejlődés egy fontos lépcsője, melynek alapját egy biztonságos belső kapcsolat adja. Az örömet nyújtó egyedüllét olyan szükség, melynek során megtapasztalhatjuk a csak ránk jellemzőt, megerősíthetjük kapcsolatunkat önmagunkkal, biztosítva érezhetjük létezésünk kontinuitását. Ez a megközelítés lehet az, amely meg tudja szabadítani az illetőt a szélsőségesen védekező fizikai visszahúzódástól [4]. Az egyedüllét és a magány éles különbségét a hikikomorik esetében is érzékelhetjük. A magány az egyedüllétre való képtelenség következménye [30], és a hikikomorival élő személyekkel való terápiás munka célja is az lehet, hogy a magánytól az örömet nyújtó egyedüllét biztonságos világába vezessük őket, mely már nem igényli azt, hogy másoktól, a külső világtól fizikailag elhatárolják magukat. Ebben segíthetnek számukra a pszichodinamikus módszerek, óvatos, empatikus megközelítésen keresztül.

\section{Következtetés}

A hikikomori állapotról mára egyértelműen globális jelenségként beszélhetünk [5]. Az állapot megjelenése és az internet térnyerésének kezdete majdnem egy időben zajlott, amit összevetve azzal, hogy a hikikomorival élők szívesen helyezik át életterüket az online világba, erôs gyanúnk lehet arra, hogy az internethasználat és a hikikomori állapot között valamiféle ok-okozati viszony áll fenn, bár ennek a kapcsoltságnak az iránya még további kutatások tárgyát kell, hogy képezze $[4,15]$.

A COVID-19-pandémia mentén megváltozott szociális, gazdasági helyzet olyan szorongásos, depressziós panaszok felerősödését és olyan társadalmi helyzetbeli rizikótényezőket hoz magával [16], melyek a hikikomori állapotnak is könnyen megágyaznak. A társas kapcsolatok beszúkülése mind az öngyilkosság, mind a hikikomori állapot szempontjából veszélyeztető tényező. Mindezek mellett az internet további térnyerése [23-25] is újabb löketet kapott a pandémia hatására, a távoli kapcsolattartás és a távmunka révén soha nem látott mértékben kerültek életünk középpontjába az információs és kommunikációs technológiák. A hikikomori és az internetfüggőség kéz a kézben járása [15], a veszélyeztető komorbid állapotok gyakorisági növekedése, továbbá a kényszerített hosszú távú szociális visszahúzódás miatt a COVID-19-világjárvány egyik mentálhigiénés következménye könnyen lehet a hikikomori állapot: a szélsőséges szociális visszahúzódás, a társadalomból való önkéntes kivonulás. Ez a potenciális szövődmény különösen súlyosan érintheti a fiatal korosztályokat, hiszen a pandémia következményeként előtérbe kerülő online oktatás és életvitel például a személyiségfejlődés szempontjából óriási jelentőségű valós idejü, offline kortárs kapcsolatoknak a jelentős redukcióját hozta magával.

Az állapot terápiás kezelésében és a társadalomba való visszailleszkedés elősegítésében nagyon fontos a család oktatása, az egyén otthonában tett segítő szakember általi látogatások, az egyéni támogató terápiás kapcsolat, majd később fokozatosan a csoportos helyzetekbe, majd valódi társas szituációkba való bevonás. Állatasszisztált és pszichoterápiás módszerek is alkalmasak lehetnek a kezelésben. Az előbbi a magányosság oldásában támogat, míg az utóbbi segít megszerezni azt a biztonságos mentális teret, amelynek birtokában nincs szüksége az egyénnek a folyamatos, valódi, fizikai elszigetelődésre [4]. 
Anyagi támogatás: A közlemény elkészítése a Nemzeti Agykutatási Program, KTIA-13-NAP-A-II/12 (20182022 ) és a Kiválósági Centrum Pályázat (FIKP II, 2020) támogatásával történt.

Szerzôi munkamegosztás: H. M.: Anyaggyưjtés, a kézirat elkészítése. H. R.: Anyaggyújtés, a kézirat revíziója. Cs. C.: Anyaggyưjtés. T. T.: Kutatási ötlet és tervezés, a kézirat revíziója. A cikk végleges verzióját valamennyi szerző elolvasta és jóváhagyta.

Érdekeltségek: A szerzőknek nincsenek érdekeltségeik.

\section{Irodalom}

[1] Kato TA, Sartorius N, Shinfuku N. Forced social isolation due to COVID-19 and consequent mental health problems: lessons from hikikomori. Psychiatry Clin Neurosci. 2020; 74: 506-507.

[2] American Psychiatric Association. Avoidant personality disorder In: Diagnostic and statistical manual of mental disorders. 5th edn. APA, Washington, DC, 2013.

[3] World Health Organization. The ICD-10 classification of mental and behavioural disorders. WHO, Geneva, 1993

[4] Kato TA, Kanba S, Teo AR. Hikikomori: multidimensional understanding, assessment, and future international perspectives. Psychiatry Clin Neurosci. 2019; 73: 427-440.

[5] Kato TA, Kanba S, Teo AR. Defining pathological social withdrawal: proposed diagnostic criteria for hikikomori. World Psychiatry 2020; 19: 116-117.

[6] Teo AR, Stufflebam K, Saha S, et al. Psychopathology associated with social withdrawal: idiopathic and comorbid presentations. Psychiatry Res. 2015; 228: 182-183.

[7] Rooksby M, Furuhashi T, McLeod HJ. Hikikomori: a hidden mental health need following the COVID-19 pandemic. World Psychiatry 2020; 19: 399-400.

[8] Saito T, Angles J. Hikikomori: adolescence without end. University of Minnesota Press, Minneapolis, MN, 2013

[9] Teo AR, Fetters MD, Stufflebam K, et al. Identification of the hikikomori syndrome of social withdrawal: psychosocial features and treatment preferences in four countries. Int J Soc Psychiatry 2015; 61: 64-72.

[10] Krieg A, Dickie JR. Attachment and hikikomori: a psychosocial developmental model. Int J Soc Psychiatry 2013; 59: 61-72.

[11] Hayakawa K, Kato TA, Watabe M, et al. Blood biomarkers of Hikikomori, a severe social withdrawal syndrome. Sci Rep. 2018; 8: 2884

[12] Kondo N, Sakai M, Kuroda Y. et al. General condition of hikikomori (prolonged social withdrawal) in Japan: psychiatric diagnosis and outcome in mental health welfare centres. Int J Soc Psychiatry $2013 ; 59$ : 79-86.

[13] Young KS. Internet addiction: the emergence of a new clinical disorder. Cyberpsychol Behavior 1998; 1: 237-244.

[14] Young KS. Caught in the net: how to recognize the signs of internet addiction - and a winning strategy for recovery. John Wiley and Sons, New York, NY, 1998.

[15] Kato TA, Shinfuku N, Tateno M. Internet society, internet addiction, and pathological social withdrawal: the chicken and egg dilemma for internet addiction and hikikomori. Curr Opin Psy chiatry $2020 ; 33$ : 264-270.

[16] Osváth P. Psychological outcome of COVID-19 pandemic. How can we prepare for a psychodemic crisis? [A COVID-19pandémia mentálhigiénés következményei. Hogyan tudunk felkészülni a pszichodémiás krízisre?] Orv Hetil. 2021; 162: 366-374. [Hungarian]

[17] Li J, Yang Z, Qiu H, et al. Anxiety and depression among general population in China at the peak of the COVID-19 epidemic. World Psychiatry 2020; 19: 249-250.

[18] Mamun MA, Griffiths MD. First COVID-19 suicide case in Bangladesh due to fear of COVID-19 and xenophobia: possible suicide prevention strategies. Asian J Psychiatr. 2020; 51: 102073.

[19] Reger MA, Stanley IH, Joiner TE. Suicide mortality and coronavirus disease 2019. A perfect storm? JAMA Psychiatry 2020; 77: 1093-1094.

[20] Zalsman G, Stanley B, Szántó K, et al. Suicide in the time of COVID-19: review and recommendations. Arch Suicide Res. 2020; 24: 477-482.

[21] Banerjee D, Kosagisharaf JR, Sathyanarayana Rao TS. 'The dual pandemic' of suicide and COVID-19: a biopsychosocial narrative of risks and prevention. Psychiatry Res. 2021; 295: 113577.

[22] Lazáry J. Acute effects of the first period of COVID-19 pandemic on mental state. [A COVID-19 pandémia akut hatásai a pszichés állapotra a járvány elsô szakaszában.] Neuropsychopharmacol Hung. 2020; 22: 172-177. [Hungarian]

[23] Király O, Potenza MN, Stein DJ, et al. Preventing problematic internet use during the COVID-19 pandemic: consensus guidance. Compr Psychiatry 2020; 100: 152180.

[24] Siste K, Hanafi E, Lee Thung Sen HC, et al. The impact of physical distancing and associated factors towards internet addiction among adults in Indonesia during COVID-19 pandemic: a nationwide web-based study. Front Psychiatry 2020; 11: 580977.

[25] Sun Y, Li Y, Bao Y, et al. Brief report: increased addictive internet and substance use behavior during the COVID-19 pandemic in China. Am J Addict. 2020; 29: 268-270.

[26] Teo AR, Chen JI, Kubo H, et al. Development and validation of the 25-item Hikikomori Questionnaire (HQ-25). Psychiatry Clin Neurosci. 2018; 72: 780-788. [Erratum: Psychiatry Clin Neurosci. 2019; 73: 603.]

[27] Fairbairn WR. Psychoanalytic studies of the personality. Routledge, London, 1952.

[28] Kato TA, Kanba S. Boundless syndromes in modern society: an interconnected world producing novel psychopathology in the 21 st century. Psychiatry Clin Neurosci. 2016; 70: 1-2.

[29] Winnicott DW. The capacity to be alone. Int J Psychoanal. 1958; 39: $416-420$

[30] Tényi T. Creation, passion, uniqueness. In: Psychiatry and art. Selected writings. [Alkotás, szenvedély, egyedüllét. In: Pszichiátria és múvészet. Válogatott írások.] Pécsi Tudományegyetem, Pécs, 2013; pp. 93-100. [Hungarian]

(Herold Márton,

Pécs, Rét u. 2., 7623

e-mail: herold.marton@pte.hu)

A cikk a Creative Commons Attribution 4.0 International License (https://creativecommons.org/licenses/by/4.0/) feltételei szerint publikált Open Access közlemény, melynek szellemében a cikk bármilyen médiumban szabadon felhasználható, megosztható és újraközölhetö, feltéve, hogy az eredeti szerző és a közlés helye, illetve a CC License linkje és az esetlegesen végrehajtott módosítások feltüntetésre kerülnek. (SID_1) 